\title{
Genetic Modification of Human Peripheral Blood Lymphocytes with a Transdominant Negative Form of Rev: Safety and Toxicity
}

\author{
BERNARD A. FOX, ${ }^{4,5,6}$ CLIVE WOFFENDIN, $, 1,2,5$ ZHI-YONG YANG, ${ }^{1,2}$ HONG SAN, ${ }^{2}$ \\ UDAYKUMAR RANGA, ${ }^{2}$ DAVID GORDON,${ }^{3}$ JOHN OSTERHOLZER,${ }^{4,6}$ and GARY J. NABEL ${ }^{1,2}$
}

\begin{abstract}
A transdominant mutant form of the rev gene, M10, confers resistance to infection by the human immunodeficiency virus (HIV) in vitro and is currently under investigation as a potential intervention in acquired immunodeficiency syndrome (AIDS). In this report, we examine three issues relevant to the safety of autologous transfer of human $T$ cells genetically modified with Rev M10. First, the potential for malignant transformation was assessed in vitro using interleukin-2 (IL-2) dependence and fibroblast transformation assays, and tumorigenicity was evaluated in severe combined immunodeficient (SCID) mice. Possible toxicity was evaluated by pathologic analysis following adoptive transfer of genetically modified human $T$ cells into SCID mice. Second, methods were developed that permit $T$ cell activation required for gene transfer but do not allow replication of endogenous HIV. Third, T cell function was evaluated in peripheral blood lymphocytes (PBL) of HIV-seropositive donors transduced with Rev M10 and compared to a negative control mutant, $\triangle$ Rev M10. By all criteria, no oncogenicity or toxicity was observed. Human $T$ cells transduced with these vectors did not grow in the absence of $\mathbf{L - 2}$ in vitro, and no tumors were observed following transplantation of genetically modified human cells into recipient SCID mice. Histopathological analysis of heart, lung, liver, spleen, and kidney of animals 1-21 weeks following adoptive transfer of gene-modified human $T$ cells revealed no significant abnornalities. Additionally, no differences were observed in the pattern of cytokine secretion in enriched human PBL expressing Rev M10 compared to $\triangle$ Rev M10. These results suggest that human T cells genetically unodified with Rev M10 or $\Delta \operatorname{Rev}$ M10 may be administered to patients with minimal toxicity.
\end{abstract}

\section{OVERVIEW}

Expression of Rev M10, a transdominant mutant form of the Rev gene, in $\mathbf{T}$ cell lines confers resistance to HIV in vitro. Insertion of this Rev M10 gene into PBL appears to be nontoxic and well-tolerated by SCID mice. These results demonstrate that genetic modification of $T$ cells by an antiviral gene can be performed safely and witlout overt toxicity. This finding encourages the development of therapeutic strategies to genetically protect $T$ cells to prolong their survival in HIV-infected individuals.

\section{INTRODUCTION}

$\mathbf{R}$ EV IS AN ESSENTIAL TRANS-ACTIVATOR of human immunodeficiency virus (HIV) replication (Cullen, 1991; Greene, 1991). This protein plays an important role in the transition from early to late HIV-1 gene expression, resulting in maturation of the virus and virion assembly. The description of mutant forms of Rev that inhibit viral wild-type Rev activity (Malim and Cullen, 1991) led to the demonstration that $T$ cell leukemia lines stably transduced with a transdominant mutant form of $\operatorname{Rev}(\operatorname{Rev}$ M10) were protected from HIV infection in

\footnotetext{
${ }^{1}$ Howard Hughes Medical Institute, University of Michigan Medical Center, and Departments of ${ }^{2}$ Internal Medicine, Biological Chemistry, ${ }^{3}$ Pathology, and ${ }^{4}$ Surgery, Ann Arbor, MI 48109-0650.

${ }^{5}$ An equal contribution was made by these authors to this study.

${ }^{6}$ Current Address: Earle A. Chiles Research Institute, Providence Medical Center, Portland, OR 97213-2967.
} 
vitro (Malim et al., 1992). More recently, these observations have been extended to peripheral blood lymphocytes (PBL) following retroviral transduction or particle-mediated gene transfer of vectors encoding Rev M10 or $\Delta \operatorname{Rev} M 10$, together with the neomycin resistance gene (Woffendin et al., 1994). Furthermore, expression of this transdominant mutant form of Rev did not interfere with the immunological function of EL4 and Jurkat cell lines, as determined by mitogen-stimulated release of interleukin-2 (IL-2) (Malim et al., 1992).

To determine whether autologous transfer of such genetically modified cells was feasible, additional safety and toxicity studies were required. In this study, we have evaluated the potential oncogenicity and toxicity of $T$ cells genetically modified with Rev M10. We find that these gene products exhibit no activity in fibroblast transformation assays. Proliferation of Rev M10- or $\Delta$ Rev M10-transduced PBL remained exquisitely dependent on exogenously supplied $\mathrm{IL}-2$, and adoptive transfer of Rev M10- or $\Delta \operatorname{Rev}$ M10-transduced human peripheral blood lymphocytes (PBL) into severe combined immunodeficient (SCID) mice failed to demonstrate any evidence of toxicity or pathology. These findings, together with the lack of cytokine secretion abnormalities or activation of endogenous HIV, suggest that retroviral or particle-mediated transfer of the cDNA encoding the Rev M10 gene into PBL is appropriate for further studies in humans to study survival of PBL transduced with Rev M10 or $\Delta$ Rev M10. These studies have implications for the development of $T$ cells that will be resistant to HIV infection and may help to preserve immunologic function in patients with acquired immunodeficiency syndrome (AIDS).

\section{MATERIALS AND METHODS}

\section{Media}

PBL cells were cultured in AIM V (GIBCO, Grand Island, NY), X-Vivo 15 (Whitaker, Walkerville, MD), or human complete medium (HCM) supplemented with antibiotics and 300 IU IL-2/ml. CM consisted of RPMI-1640 (GIBCO) containing $0.1 \mathrm{~m} M$ nonessential amino acids, $1 \mathrm{~m} M$ sodium pyruvate, 2 $\mathrm{m} M$ L-glutamine, and $100 \mu \mathrm{g} / \mathrm{ml}$ of gentamicin sulfate. This media was further supplemented with $10 \%$ human $A B$ serum (GIBCO), and $300 \mathrm{IU} / \mathrm{ml}$ rIL-2 (kindly provided by Chiron, Emeryville, CA). Transduced T cells were selected for expression of the $\mathrm{Neo}^{\mathrm{R}}$ gene by exposure to $300-400 \mu \mathrm{g} / \mathrm{ml}$ (active drug) of the neomycin analog G418 sulfate (Geneticin, GIBCO). Antiretroviral compounds (Delavirdine and CD4PE40) were kindly provided by The Upjohn Company (Kalamazoo, MI) and Boehringer Ingelheim Pharmaceuticals, Inc. (Nevirapine).

\section{Retroviral transduction of $P B L$}

PBL were isolated from heparinized blood by FicollHypaque density gradient centrifugation, as previously described (Woffendin et al., 1994). These cells were washed three times in Hanks' balanced salt solution (HBSS) and resuspended at $1 \times 10^{6}$ cells $/ \mathrm{ml}$ in HCM or AlM V. PBL were plated into 24-well tissue culture plates previously coated with anti-CD3 (OKT3, $10 \mu \mathrm{g} / \mathrm{ml}$ in HBSS overnight) or stimulated with 5 $\mu \mathrm{g} / \mathrm{ml}$ phytohemagglutinin (PHA) for up to $72 \mathrm{hr}$. Following stimulation, cells were infected for 6-12 hr with $\psi$ Crip supernatant of either pLJ Rev M10 or pLJ $\triangle$ Rev M10 retroviruses (Woffendin et al., 1994) with $5 \mu \mathrm{g} / \mathrm{ml}$ Polybrene. Cells were incubated at a density of $1 \times 10^{6} /$ well in a 24 -well plate containing $1 \mathrm{ml}$ of $\psi$ Crip supernatant and $1 \mathrm{ml}$ of AIM-V medium and $300 \mathrm{IU}$ of IL-2/ml. Following infection, cells were selected in AIM V medium containing $300 \mathrm{IU}$ of IL- $2 / \mathrm{ml}$ and $300 \mu \mathrm{g} / \mathrm{ml}$ G418 (active).

\section{Particle-mediated gene transfer}

Plasmid DNA was linearized by digestion with Aat II restriction enzyme, extracted using phenol chloroform, precipitated with ethanol, and resuspended in Tris-EDTA buffer $\mathrm{pH}$ 8.0 to a final concentration of $1 \mathrm{mg} / \mathrm{ml}$. Microscopic gold particles (1.6 $\mu \mathrm{m}$ in diameter) were prepared. The plasmid DNA was coated onto the beads by precipitation with $\mathrm{CaCl}_{2}$ and spermidine, followed by ethanol washes. The cells were then transfected as previously described (Woffendin et al., 1994). A total of $800 \mathrm{ng}$ of DNA was used to transduce $10 \times 10^{6}$ cells. Conditions for stimulation of PBL and G418 selection were as described for the retroviral transduction procedures.

\section{Cell proliferation assays}

Ten million CD3-stimulated Rev M10- or $\Delta$ Rev M10-modified PBL were washed twice in medium without IL-2 and resuspended at $5 \times 10^{5}$ cells $/ \mathrm{ml}$ in AIM V, supplemented with or without $300 \mathrm{IU}$ of $\mathrm{IL}-2 / \mathrm{ml}$. The number of viable cells present in the cultures was determined by trypan blue dye exclusion. When it was apparent by microscopic examination that all the cells in these cultures without IL-2 were nonviable, the flasks were maintained for at least an additional 2 weeks to confirm that no transformed cells grew out of the nonviable cultures.

\section{Adoptive transfer of Rev M10/ARev M10-transduced PBL}

SCID mice (Jackson Laboratories, Bar Harbor, ME) were housed in the SCID mouse facility at the University of Michigan under appropriate conditions. Mice received an i.v. and/or i.p. injection of $2 \times 10^{7}$ to $3 \times 10^{8}$ PBL modified by retroviral transduction or particle-mediated gene transfer and selected as described above. Following adoptive transfer, animals were observed weekly for evidence of toxicity and were sacrificed at times specified. Animals were necropsied and examined for gross abnormalities. Sections of heart, lung, liver, spleen, and kidney were recovered for histological examination.

\section{Cytokine analysis of transduced $P B L$}

IL-4 and granulocyte-macrophage colony-stimulating factor (GM-CSF) levels were measured using a standard ELISA protocol following manufacturers recommendations (Pharmingen). Cells $\left(1 \times 10^{6}\right.$ cells $\left./ \mathrm{ml}\right)$ were plated in six-well plates that had been previously coated with or without immobilized OKT-3 (10 $\mu \mathrm{g} / \mathrm{ml})$. Following incubation for $24 \mathrm{hr}$ at $37^{\circ} \mathrm{C}$, supernatants were collected and assayed for cytokine levels.

\section{$3 Y 1$ Cell transformation assay}

Rat fibroblast cells (3Y1) growing in 10-cm-diameter tissue culture dishes were transduced with ( $3 \mu \mathrm{g})$ linearized RSV/TAR 
Rev M10 or RSV/TAR $\Delta$ Rev M10 plasmids by particle-mediated gene transfer or by infection with the Rev MIO or $\Delta R e v$ M10 retroviral vectors (producer titers $10^{5}-10^{6} \mathrm{pfu} / \mathrm{ml}$ ). The total number of foci of cells representing transformed cells on each dish were counted microscopically 3 weeks post transduction. A positive control for the transformation assay consisted of $3 \mathrm{Yl}$ cells that had been $\mathrm{CaPO}_{4}$-transfected with a $\mathrm{v}$-src expression vector (pZAS 4, $3 \mu \mathrm{g}$ ).

\section{Quantitative PCR analysis}

To analyze gene transfer frequencies, limiting-dilution PCR was performed. Briefly, cells carrying Rev M10 or $\Delta$ Rev M10 were diluted into CEM cells at progressively lower cell numbers. Chromosomal DNA was prepared from a total of $10^{5}$ cells using a quick lysis method. The cell pellet was suspended in $10 \mathrm{~m} M \mathrm{KCl}, \mathrm{l} \mathrm{m} M$ Tris- $\mathrm{HCl} \mathrm{pH} 8.3,0.25 \mathrm{mM} \mathrm{MgCl}_{2}(50 \mu \mathrm{l})$

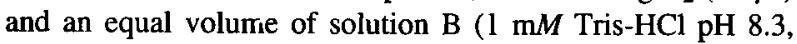
$0.25 \mathrm{mM} \mathrm{MgCl}, 0.1 \%$ Tween-20, $0.1 \% \mathrm{NP}-40$, and $50 \mathrm{mg} / \mathrm{ml}$ proteinase $\mathrm{K}$ ). The reaction mixture was incubated at $56^{\circ} \mathrm{C}$ for $1 \mathrm{hr}$ and at $95^{\circ} \mathrm{C}$ for $20 \mathrm{~min}$. The nucleotide sequences for $\mathrm{Rev}$ M10 and $\triangle \operatorname{Rev}$ M10 of the primers were chosen to match each vector uniquely as follows: sense primers (1) for $\mathrm{pLJ}$ Rev M10 (9335A), 5'-TCTTGTCTGCCAGATCCCGGATCCAT-3'; (2) for pLJ $\triangle$ Rev M10 (3111B), 5'-TTAAGTGACCAGCTACAGTCGGAA-3'; (3) for PRSV/TAR Rev M10 (3112B), 5' -GCTTAAGCTCATGGCAGGAA-3'; (4) for PRSV/TAR Rev M10 (3113B), 5' -GGAACCCAGTGCTTAAGCTTG-3' ' A common antisense primer (3060B) 5'-CTCGTTACAATCAAGAGTTCTCAGATC- $3^{\prime}$ was used in all reactions. PCR detection of proviral DNA was standardized using serial dilutions of ACH2 cells in a total of $10^{5}$ CEM cells; HIV proviral DNA was detected using the gag-specific PCR primers SR38 and SR39.

\section{RESULTS}

\section{Gene transfer does not alter proliferation of $P B L$}

Rev M10, or the negative control, $\Delta \operatorname{Rev} M 10$, was transferred into PBL by either retroviral vector or particle-mediated gene transfer. These cell suspensions were selected in G418, and a population of G418-resistant cells was recovered and expanded as described previously (Woffendin et al., 1994). The percentage of transduced cells in the lymphocyte population, as estimated by limiting cell dilution PCR using Rev M10- and $\Delta \operatorname{Rev} M 10$-specific primers, was found to be greater than $0.1 \%$ and $10 \%$ day 4 post-transduction for retrovirally and particlemediated gene transfer procedures, respectively. At day 22 , the levels had increased to at least $2.5 \%$ for the retrovirus and $25 \%$ for particle-mediated transduction procedures. Variability was seen in the transduction frequencies between individual experiments. In many subsequent experiments, transduction frequencies obtained after transduction were much higher than for these particular experimental groups (Woffendin et al., 1994). The proliferation of anti-CD3-activated PBL populations containing the Rev M10 or $\Delta \operatorname{Rev}$ M10 vectors was evaluated under culture conditions in the presence or absence of IL-2. To demonstrate that transduction with Rev M10 does not interfere with regulation of $\mathrm{T}$ cell growth, $1 \times 10^{7} \mathrm{PBL}$ were tested for IL-2 independent proliferation. In theory, such an assay could potentially detect a transformation event as rare as 1 in $10^{7}$ PBL. Cells transfected by retroviral-mediated gene transfer with Rev M10 or $\Delta$ Rev M10 were passaged for up to six culture cycles and proliferation was assessed (Fig. 1A). PBL incubated with IL-2 continued to proliferate, although at a reduced rate as compared to nontransduced, unselected CD3-stimulated PBL (data not shown). However, when the anti-CD3-activated PBL were cultured in media devoid of their requisite growth factor, IL-2, they ceased proliferating and died rapidly. These cultures were maintained and followed for a minimum of 25 days to ensure that a rare clone of cells had not escaped dependence on IL-2.
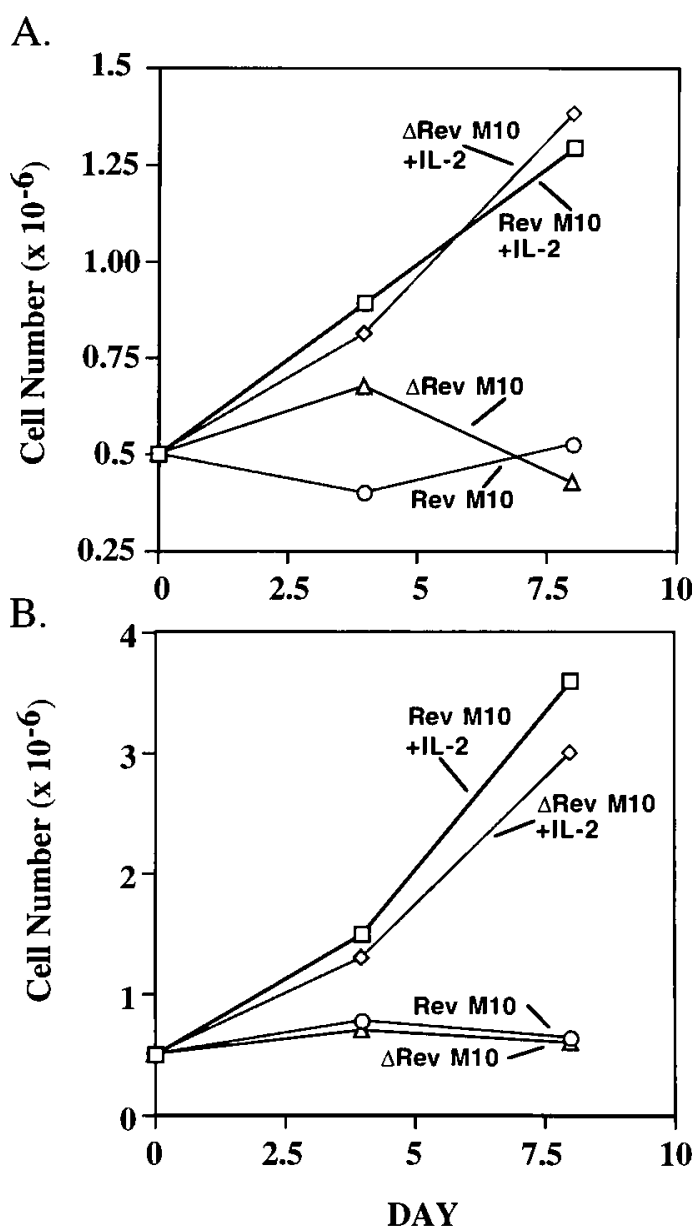

FIG. 1. IL-2 dependence of PBL genetically modified with Rev M10 or $\Delta$ Rev M10. Cells transduced by retroviral or particle-mediated gene transfer were maintained in cell culture for 22 days, washed twice in media without IL-2, and resuspended at a density of $5.0 \times 10^{5} \mathrm{cells} / \mathrm{ml}$ in the presence or absence of IL-2 (in fresh medium without G418 or antiviral agents). Growth was then monitored in the presence of IL-2 (Rev M10, $\square ; \Delta \operatorname{Rev} \mathrm{M} 10, \diamond)$ or after withdrawal of IL-2 (Rev M10, O; $\Delta \operatorname{Rev} \mathrm{M} 10, \Delta)$ and expressed as total cell numbers for the indicated time periods after withdrawal of IL-2. Cultures were maintained at a cell density of $0.5-1.5 \times 10^{6}$ cells $/ \mathrm{ml}$. In the absence of IL-2, there was no increase in cell number in either retrovirally transduced (A) or particle-mediated transfected (B) cells. Cultures were followed for 25 days in the absence of IL2. No viable cells were seen. 
Table 1. Effect of Delavirdine or Nevirapine AND CD4-PE40 ON MURINE AMPHOTROPIC RETROVIRUS INTEGRATION AND EXPRESSION

\begin{tabular}{lcc}
\hline Treatment & Concentration & Positive Cells \\
\hline None & - & $85 / 82 / 93$ \\
Delavirdine & $1 \mu M$ & $70 / 95$ \\
Delavirdine & $5 \mu M$ & $73 / 81$ \\
Delavirdine & $20 \mu M$ & $26 / 45$ \\
Nevirapine & $40 \mathrm{n} M$ & $68 / 74$ \\
Nevirapine & $100 \mathrm{n} M$ & $97 / 83$ \\
Nevirapine & $200 \mathrm{n} M$ & $87 / 81$ \\
AZT & $2 \mu M$ & 0.1 \\
AZT & $10 \mu M$ & $0 / 0$ \\
Nevirapine/CD4-PE40 & $40 \mathrm{n} M / 4 \mathrm{n} M$ & $74 / 94$ \\
Delavirdine/CD4-PE40 & $1 \mu M / 4 \mathrm{n} M$ & $65 / 82$ \\
Delavirdine/CD4-PE40 & $5 \mu M / 12 \mathrm{n} M$ & $103 / 89$ \\
\hline
\end{tabular}

Murine amphotropic retroviral $\mathrm{pLJ}-\beta$-Gal supernatant $\left(10^{4}\right.$ G418 resistant colony forming units) produced from $\psi$ Crip producer cells was inoculated onto 293 cells growing in 6-well plates. The wells contained $2 \mathrm{ml}$ of medium with the indicated concentrations of antiviral compounds. After 3 days of incubation, cells were fixed and stained for $\beta$-Gal activity by $\mathrm{X}$ Gal staining, and the number of positive cells per duplicate well counted. Control untransduced cells showed no X-Gal staining.

Similar results were observed in PBL transduced by particlemediated gene transfer (Fig. 1B). Cultures evaluated by a careful microscopic examination revealed that no viable cells remained.

\section{Specific inhibition of endogenous HIV activation with} $H I V-1$ antiviral agents

The process of $\mathrm{T}$ cell stimulation, needed to promote optimal gene transfer, can induce viral replication (Zagury et al., 1986). To transduce and expand human PBLs derived from HIV-positive patients, activation of endogenous provirus must thus be avoided. To address this problem, we developed conditions for activation and expansion of lymphocytes that selectively block productive HIV replication without affecting transduction. A nonnucleoside reverse transcriptase inhibitor was employed that specifically inhibits HIV-1 in vitro but does not affect murine retroviral reverse transcription. Either of two different agents, delavirdine (U90152s) or nevirapine, were used. Both inhibitors noncompetitively bind to HIV-l reverse transcriptase (Richman et al., 1991; Dueweke et al., 1993). They were used alone or in combination with a second antiviral, a chimeric toxin protein consisting of a CD4 domain fused to Pseudomonas aeruginosa exotoxin (PE) A (CD4-PE40), which exerts its effect on cells already infected with HIV (Chaudhary et al., 1988).

To determine whether a nonnucleoside reverse transcriptase inhibitor and CD4-PE40 could inhibit HIV replication in vitro and not interfere with transduction by the vector, we infected the human renal epithelial cell, 293, with a murine amphotropic retroviral vector encoding $\beta$-galactosidase at an moi of 0.1 in the presence or absence of these agents (Table 1). Either delavirdine or nevirapine, alone or in combination with CD4-PE40 showed minimal inhibition of murine retroviral transduction. In contrast, azidothymidine (AZT), which is not HIV-1 selective, inhibited transduction by the murine retroviral vector (Table 1). Delavirdine or nevirapine alone or in combination with CD4PE40, however, effectively suppressed HIV replication to undetectable RT levels in freshly infected lymphocyte cultures over a 3-week period (Grob et al., 1992; Skoog et al., 1992; Vasudevachari et al., 1992; data not shown).

To evaluate the efficacy in patient cells in vitro, lymphocytes from an asymptomatic $\mathrm{HIV}^{+}$patient $\left(\mathrm{CD} 4^{+}\right.$count $\left.\sim 400\right)$ were activated in the presence of these drugs. Proviral HIV DNA content was determined by limiting dilution PCR for 22 days post-stimulation. A significant reduction in lymphocyte proviral DNA content was observed in antiviral treated cultures compared to untreated cells. Before treatment, between 1:250-1:2,500 cells were HIV-positive using gag-specific primers. After treatment for 8 days, $\sim 1: 25,000$ were positive with nevirapine/CD4-PE40 and fewer than 1:50,000 (the limit of our PCR detection system) with delavirdine/CD4-PE40 treatment (data not shown). No p24 antigen (less than the detection limit of $\sim 2 \mathrm{pg} / \mathrm{ml} \mathrm{p} 24$ ) or reverse transcriptase activity above baseline was detected in culture supernatants over a culture period of 22 days. Thus, these agents were effective in reducing HIV activation in cell culture without interfering with the

Table 2. Pathologic Analysis of SCID Mice InJected with Retroviral Vector-Modified Human T Cells

\begin{tabular}{|c|c|c|c|c|c|c|c|c|c|}
\hline Sample & Cells & Vector & $\begin{array}{c}\text { Number of } \\
\quad \text { cells } \\
\text { transferred }\end{array}$ & $\begin{array}{l}\text { Time of } \\
\text { sacrifice } \\
\text { (weeks) }\end{array}$ & Heart & Lung & Liver & Spleen $^{\mathrm{a}}$ & Kidney \\
\hline \multicolumn{10}{|c|}{ Rev M10 } \\
\hline 1 & PBL & RSV M10 & $3 \times 10 \mathrm{E} 8$ & $8 . \dot{5}$ & Normal $^{b}$ & Normal ${ }^{\mathrm{c}}$ & Normal & Lymphopenia & Normal \\
\hline 2 & PBL & RSV M10 & $10 \mathrm{E} 8$ & 8.5 & Normal ${ }^{b}$ & Normal ${ }^{c}$ & Normal & Lymphopenia & Normal \\
\hline 3 & PBL & RSV M10 & $10 \mathrm{E} 8$ & 8.5 & Normal $^{\mathrm{d}}$ & Normal $^{c}$ & Normal & Lymphopenia & Normal \\
\hline 4 & PBL & None & $10 \mathrm{E} 8$ & 8.5 & Normal & Normal $^{c}$ & Normal & Lymphopenia & Normal \\
\hline \multicolumn{10}{|c|}{$\Delta$ Rev $M l 0$} \\
\hline 5 & PBL & RSV $\Delta \mathrm{M} 10$ & $10 \mathrm{E} 8$ & 8.5 & Normal & Normal $^{c}$ & Normal & Lymphopenia & Normal \\
\hline 6 & PBL & RSV $\Delta \mathrm{M} 10$ & $10 \mathrm{E} 8$ & 8.5 & Normal & Normal $^{\mathrm{c}}$ & Normal & Lymphopenia & Normal \\
\hline
\end{tabular}

${ }^{a}$ Lymphopenia noted, due to immunodeficient condition of SCID mice.

${ }^{b}$ Heart: Focal epicardial fibrosis/calcification (minor pathological changes of no clinical significance).

'Lung: Peribronchial lymphoid aggregates (minor pathological changes of no clinical significance).

${ }^{\mathrm{d}}$ Heart: Focal epicardial calcification (minor pathological changes of no clinical significance). 


\section{Dear Colleague:}

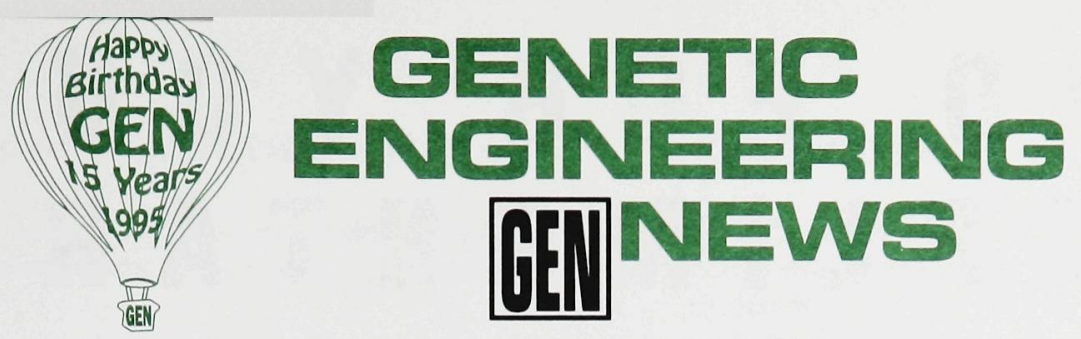

If you are not already receiving a subscription to GENETIC ENGINEERING NEWS, here is an exceptional opportunity to receive a * complimentary subscription. Simply fill out and return the postage-paid card below.

Now in its 15th year, GENETIC ENGINEERING NEWS is published biweekly. Twice each month,

21 times a year, GEN covers the biotechnology market from applied research through scale-up and commercialization. GEN provides important information spanning academia, government, and industry.

GENETIC ENGINEERING NEWS is widely recognized as the voice of the biotechnology industry and prominent leaders such as Jimmy Carter, NJ Governor Christine Whitman, and Dr. Henry Miller have contributed guest editorials.

I'm looking forward to sending you a * complimentary subscription to GENETIC ENGINEERING NEWS, which will begin as soon as we receive the qualification card below. The card is postage-paid, so just complete and sign it, drop it in the mail, and we'll begin your *complimentary subscription promptly.

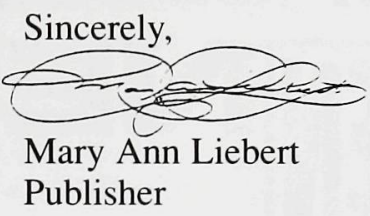

*Complimentary subscriptions are only available to qualified individuals and are subject to acceptance by GENETIC ENGINEERING NEWS. Libraries may order GENETIC ENGINEERING NEWS from the publisher.

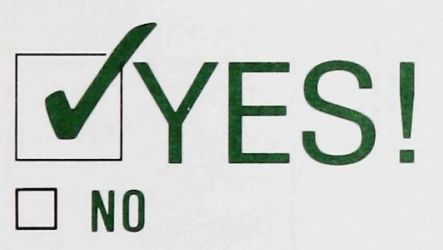

(please print)

First name

Organization

Address/Box\#

City

State Zip

Country/Postal Code

Phone

A. Job Function (One Only)

3.0 $\square$ Technical Management $3.5 \square$ Clinical Medicine

$3.1 \square \mathrm{CEO} /$ Financial $\quad 3.6 \square$ Biosafety

3.2 $\square$ Production/Process $\quad 3.7 \square$ Law/Regulatory

3.4 $\square$ Research/Development 3.8 $\square$ Quality Control Assurance 4.3 $\square$ Mech. Eng.

B. Technologies (All Areas)

5.0 $\square$ Cell Fusion

5.1 Recombinant DNA 6.0 $\square$ Protein/Drug Design

$5.2 \square$ Cell/Tissue Culture

$5.3 \square$ Enzymology

$5.4 \square$ Fermentation

$5.5 \square$ Purification

$5.6 \square$ Separations

6.2 $\square$ Drug Delivery

$6.9 \square$ Bioprocess

6.5 DNA/RNA Synthesis 7.1 $\square$ Electrophoresis $7.8 \square$ Carbohydrate

A.2 $\square$ Spectrophotometry $7.9 \square$ Filtration

C. Area of Focus (All Areas)

$2 \square$ Hazardous Waste $\quad 8.6 \square$ Biological

Processing

8.7 Diagnostics

$8.8 \square$ Veterinary $9.2 \square$ Bioremediation

8.9 $\square$ Clinical Tests $9.3 \square$ Supplier/Reagents

9.0 $\square$ Food Processing $9.4 \square$ Supplier/instrumentation

9.1 $\square$ Environmental $9.9 \square$ Others

D. Status of Organization's Product Development (All Areas)

$10.0 \square$ Not Applicable $\quad 10.2 \square$ Pilot/Scale-up

$10.1 \square$ Research/Development $\quad 10.3 \square$ Production/Process

E. Organization (One Only)

$11.0 \square$ Industry

$11.1 \square$ Academic

$11.2 \square$ Government

$11.3 \square$ Institutional

10.4 $\square$ Packaging

$11.4 \square$ Hospital

11.5 $\square$ Private Practice
Signature

Date

Title:

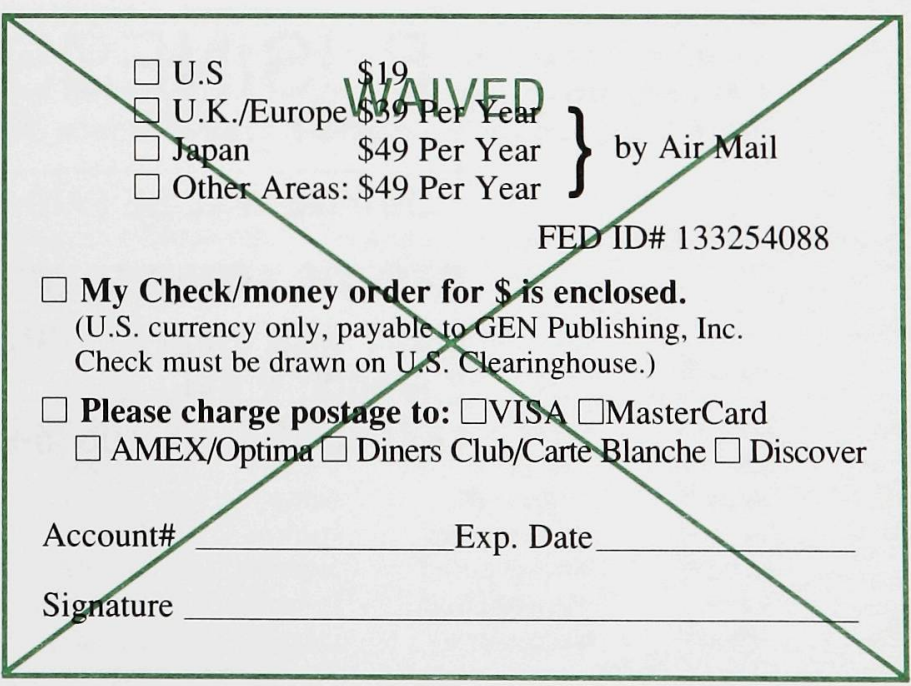

Buying influence

$\square 12.0$ Authorize

$\square 12.1$ Recommend

$\square 12.2$ Specify

This subscription cannot be processed unless it is fully completed, signed and dated. Subscriptions are subject to acceptance by GENETIC ENGINEERING NEWS 
S E N D F O R Y O U R

C O M P L I M E N T A R Y

S U B S C R I P T I O N

\section{TO}

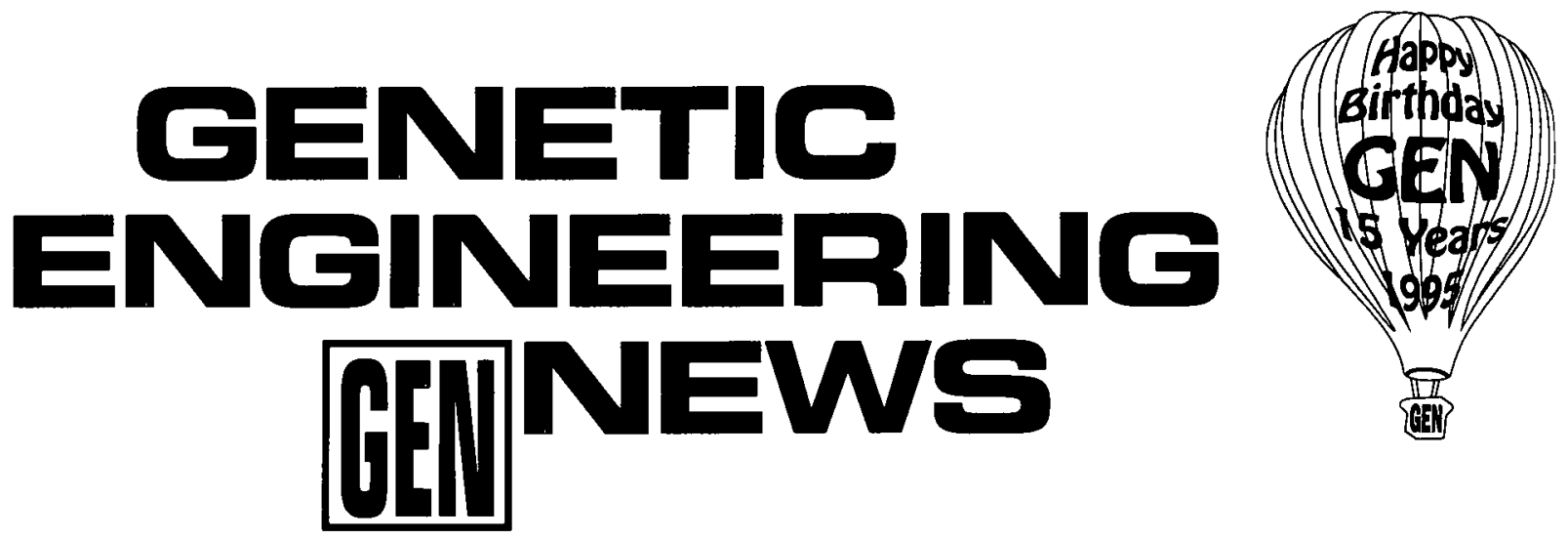

Mail this postage paid card TODAY!

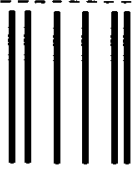

NO POSTAGE

NECESSARY

IF MAILED

IN THE

UNITED STATES

\section{BUSINESS REPLY CARD \\ FIRST CLASS PERMIT NO. 5443 NY, NY}

POSTAGE WILL BE PAID BY ADDRESSEE

GENETIC ENGINEERING NEWS

MARY ANN LIEBERT, INC. PUBLISHERS

2 MADISON AVE.

LARCHMONT, NY 10538-9952 
murine retroviral vector. Similarly, these agents had no major effect on gene transfer efficiencies by particle-mediated gene transfer.

PBL transduced with Rev M10 or $\triangle$ Rev MlO fail to form tumors and show a lack of toxicity in SCID mice

Next, we sought to determine whether transduced $\mathrm{T}$ cells could be administered to SCID mice without signs of overt toxicity. Eight mice received 1-3 $\times 10^{8}$ PBL transduced with retroviral vectors for either Rev M10 or $\Delta \operatorname{Rev}$ M10. Following adoptive transfer of $\mathrm{T}$ cells, mice were observed several times each week and appeared healthy at times ranging from 18 to 60 days post infusion. On gross examination at necropsy, all animals appeared normal, with no evidence of overt malignancy. To determine whether toxicity was observed in major organs following adoptive transfer of these modified $T$ cells, histological analysis of the heart, lung, liver, kidney, and spleen was performed on tissues obtained from the sacrificed animals. No significant immune or inflammatory changes from the underlying immunodeficiency, or cytopathology was observed in 6 animals that underwent pathologic analysis (Table 2). These data suggest that up to $3 \times 10^{8} \mathrm{PBL}$ transduced with Rev M10 or $\Delta$ Rev M10 could be adoptively transferred into SCID mice without deleterious effects.

PBL modified by particle-mediated Rev MIO gene transfer show a lack of oncogenicity or toxicity in SCID mice

Six SCID mice received adoptive transfer of $2-4 \times 10^{7} \mathrm{PBL}$ transfected by particle-mediated gene transfer. Mice were sacrificed at $1,2,3$, and 21 weeks following adoptive transfer. Similar to the recipients of transduced PBL, no evidence of toxicity was observed in any animal (Table 3 ). Gross examination of these animals failed to reveal abnormalities and no major evidence of cytopathology, immune, or inflammatory changes was observed in any animal. This second set of experiments maintained 3 animals for 21 weeks to evaluate the safety of PBL modified by particle-mediated Rev M10 gene transfer over a longer time period.

\section{Transformation assays}

The potential for malignant transformation was assessed further in vitro by a fibroblast transformation assay. Cells (3Y1) were transduced with RSV/TAR Rev M10 or RSV/TAR $\Delta$ Rev M10 plasmids using particle-mediated gene transfer or by infection with the Rev M10 or $\Delta$ Rev M10 retroviral vectors. Following transduction, cells were grown for 3 weeks after which foci representing transformed cells were counted microscopically. No foci were seen in any Rev M10- or $\Delta$ Rev M10transduced cells. In contrast, positive controls consisting of $3 \mathrm{Y} 1$ cells transfected with ZAS 4, a v-src expression vector, gave 208 foci.

\section{Toxicity of DNA-coated gold particles}

A safety consideration that is unique to particle-mediated gene delivery is the potential for injection of gold particles into patients. This possibility is unlikely, because the particles are removed by low-speed centrifugation on human serum albumen prior to reinfusion of transduced cells; however, the general question of toxicity of plasmid gold particles in humans was discussed. To address this question, DNA-coated gold particles were tested in 6- to 8-week-old BALB/c female mice to determine their potential for toxicity. Gold particles coated with RSV/Rev M10 plasmid were injected intravenously ( 8 mice) and a negative control group received normal saline ( 8 mice). The test group was injected with $0.8 \mu \mathrm{g}$ of DNA and $500 \mathrm{mg}$ of gold microspheres $(1,000 \times$ greater than are likely to be inadvertently administered to patients). After 10 days, the recipients were sacrificed, and the organs were removed and examined both grossly and histologically. Serum samples were obtained prior to injection, and at the time recipient animals were sacrificed and were analyzed for evidence of alterations in selected serum enzymes and chemistries. These studies have failed to demonstrate any signs of toxicity (Table 4).

\section{IL-4 and GM-CSF cytokine production in Rev MIO- and $\triangle R e v$ M10-transduced PBL stimulated with anti- CD3 antibody}

To see whether expression of Rev M10 could alter cytokine production in transduced PBL populations, PBL obtained from an asymptomatic HIV seropositive donor were transduced with linearized RSV/TAR Rev M10 or RSV/TAR $\Delta$ Rev M10 plasmids by particle-mediated gene transfer or by infection with the Rev M10 or $\Delta \operatorname{Rev~M10~retroviral~vectors~as~described~previ-~}$ ously (Woffendin et al., 1994). Following transduction, cells were selected in $\mathrm{G} 418$ (300 $\mu \mathrm{g} / \mathrm{ml}$ active) for up to 3 weeks.

Table 3. Pathologic Analysis of SCID Mice Injected with Particle-Mediated Vector-Modified Human T Cells

\begin{tabular}{|c|c|c|c|c|c|c|c|c|}
\hline Sample & Cells & Vector & $\begin{array}{c}\text { Time of } \\
\text { sacrifice } \\
\text { (weeks) }\end{array}$ & Heart & Lung & Liver & Spleen $^{\mathrm{a}}$ & Kidney \\
\hline 1 & PBL & RSV M10 & 1 & Normal & Normal & Normal & Lymphopenia & Normal \\
\hline 2 & PBL & RSV M10 & 2 & Normal & Normal & Normal & Lymphopenia & Normal \\
\hline 3 & PBL & RSV M10 & 3 & Normal & Normal & Normal & No data & Normal \\
\hline 4 & PBL & RSV Ml0 & 21 & Normal & Normal $^{b}$ & Normal & Lymphopenia & Normal \\
\hline 5 & PBL & RSV Ml0 & 21 & Normal & Normal $^{b}$ & Normal & Lymphopenia & Normal \\
\hline 6 & PBL & RSV M10 & 21 & Normal & Normal & Normal & Lymphopenia & Normal \\
\hline Control & PBL & None & 3 & Normal & Normal & Normal & Lymphopenia & Normal \\
\hline
\end{tabular}

aLymphopenia noted, due to immunodeficient condition of SCID mice.

bLung: Peribronchial lymphoid aggregates (minor pathological changes of no clinical significance). 
Table 4. Intravenous Injection of pRSV/TAR Rev M10 Plasmid-Coated Gold Beads

\begin{tabular}{|c|c|c|c|c|c|c|c|c|}
\hline \multirow[b]{2}{*}{ Mouse injection } & \multicolumn{8}{|c|}{ Organ pathology } \\
\hline & Brain & Heart & Kidney & Liver & Lung & Muscle & Ovary & Spleen \\
\hline 1. Saline & Normal & Normal $^{2}$ & Normal & Normal $^{1}$ & Normal & Normal & Normal & Normal \\
\hline 2. & Normal & Normal & Normal & Normal & Normal & Normal & No data & Normal \\
\hline 3. & Normal & Normal & Normal & Normal & Normal & Normal & Normal & Normal \\
\hline 4. & Normal & Normal $^{2}$ & Normal & Normal & Normal & Normal & Normal & Normal \\
\hline 5. & Normal & No data & Normal & Normal & Normal & Normal & Normal & Normal \\
\hline 6. & Normal & Normal & Normal & Normal & Normal $^{3}$ & Normal & Normal & Normal \\
\hline 7. & Normal & Normal & Normal & Normal & Normal $^{3}$ & Normal & Normal & Normal \\
\hline 8. & Normal & Normal & Normal & Normal $^{1}$ & Normal $^{3}$ & Normal & Normal & Normal \\
\hline 9. Coated Beads & Normal & Normal & Normal & Normal & Normal $^{3}$ & Normal & Normal & Normal \\
\hline 10. & Normal & Normal & Normal & Normal & Normal $^{3}$ & Normal & Normal & Normal \\
\hline 11. & Normal & Normal & Normal & Normal & Normal $^{3}$ & Normal & No data & Normal \\
\hline 12. & Normal & Normal & Normal & Normal & Normal & Normal & Normal & Normal \\
\hline 13. & Normal & Normal & Normal $^{4}$ & Normal $^{1}$ & Normal & Normal & Normal & Normal \\
\hline 14. & Normal & Normal & Normal & Normal & Normal $^{3}$ & Normal & Normal & Normal \\
\hline 15. & Normal & Normal & Normal & Normal & Normal $^{3}$ & Normal & Normal & Normal \\
\hline 16. & Normal & Normal & Normal & Normal & Normal $^{5}$ & Normal & Normal & Normal \\
\hline
\end{tabular}

The following are incidental findings of no pathological significance.

1. Focal cluster of mononuclear inflammatory cells

2. Focal calcification of epicardium

3. Focal peribronchial lymphoid aggregates

4. Minimal focal very recent tubular necrosis

5. Focal endobronchial cluster of foamy macrophages. Focal peribronchial lymphoid aggregates. Focal interstitial macrophage clusters with particulate inclusions.

The capacity of these transduced cells to respond to an immunological stimulus was tested by culturing cells with immobilized anti-OKT3. Culturing cells under these conditions, which cross-links the $\mathrm{T}$ cell receptor (TCR), is thought to mimic immunologic recognition of antigen by the TCR, resulting in T cell proliferation and cytokine release. For each experiment, control $\mathrm{T}$ cell populations were cultured in $\mathrm{CM}$ without being exposed to immobilized anti-OKT3. Cytokine release by OKT3-stimulated $\mathrm{T}$ cells was divided by cytokine released by control nonstimulated $\mathbf{T}$ cells and plotted as fold stimulation (Fig. 2). Cytokine release assays were performed at intervals throughout the experiment. No significant differences in the fold stimulation in IL-4 and GM-CSF levels from PBL were noted either by retroviral or particle-mediated gene transfer (Fig. 2). During this experiment, antiviral agents delavirdine (5 $\mu M)$ and CD4-PE-40 (4 $\mathrm{n} M)$ were supplemented in the medium to prevent any possible spread of HIV infection during the stimulation procedures. PCR analysis of PBLs for HIV proviral copy number using gag-specific primers showed less than 1 in 25,000 cells were infected throughout the experiment; no p24 antigen could be detected in the culture supernatants (data not shown).

\section{DISCUSSION}

In this study, three questions have been addressed that are relevant to the application of gene transfer technology for the treatment of individuals infected with HIV. First, the effect of Rev M10 or $\Delta$ Rev M10 on human lymphocyte proliferation was analyzed. Second, methods were developed to suppress HIV replication in activated $\mathbf{T}$ cells from seropositive donors. Finally, the possible toxicity of Rev M10 gene expression in these cells was analyzed in vitro and in immunosuppressed animals. We have found no evidence of abnormal growth properties, toxicity or tissue pathology in this model. Endogenous HIV replication was suppressed, despite effective $T$ cell activation. These findings suggest that transfer of Rev M10 or $\Delta R e v$ M10 vectors provide no readily apparent contraindications to use in humans.

Although previous clinical trials using retroviral vectors to integrate constructs into PBL failed to demonstrate acute toxicities, it was important to ascertain whether integration and expression of the transdominant negative Rev protein could affect lymphocyte proliferation or function. Previous studies demonstrated that constitutive Rev M10 expression did not interfere with mitogen-induced IL-2 secretion by murine or human T cell lines (Malim et al., 1992). However, because these $\mathrm{T}$ cell lines normally exhibit unregulated growth in vitro, the effect of Rev M10 or $\Delta$ Rev M10 expression on cell growth could not be evaluated. Therefore, normal PBL were targeted for transfer of the Rev M10 or $\Delta$ Rev M10 constructs and examined for alterations in cell growth. Results of these studies find no evidence that transfer of the Rev M10 or $\Delta$ Rev M10 gene into PBL may lead to a malignant transformation. To test the potential of these gene-modified cells to exhibit a malignant transformation in vivo, PBL were infused into SCID mice.

The SCID mouse offers an opportunity to grow and study human cells in an in vivo environment (Mosier et al., 1991). Long-term engraftment of SCID mice with human peripheral blood lymphocytes has been somewhat controversial. On the other hand, short-term survival of human $\mathrm{T}$ cells is believed to be not problematic in this model (Mosier et al., 1991). Therefore, we have used this animal model to address safety issues relevant to the expression of Rev M10 transduced PBL 


\section{A. Particle-mediated Gene Transfer}
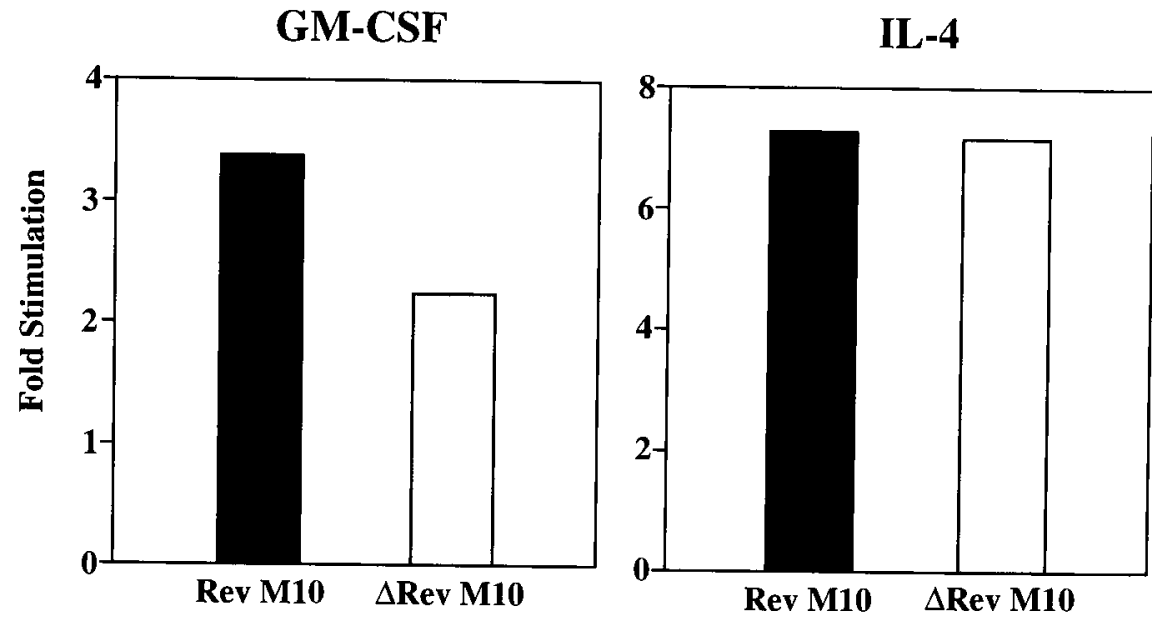

B. Retroviral Transduction

GM-CSF

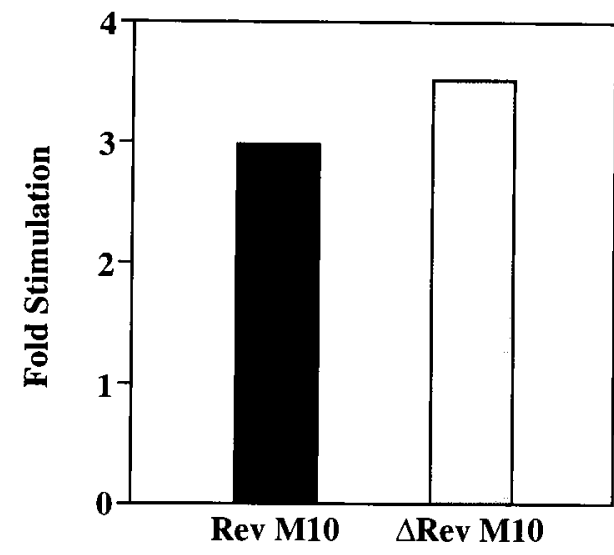

IL-4

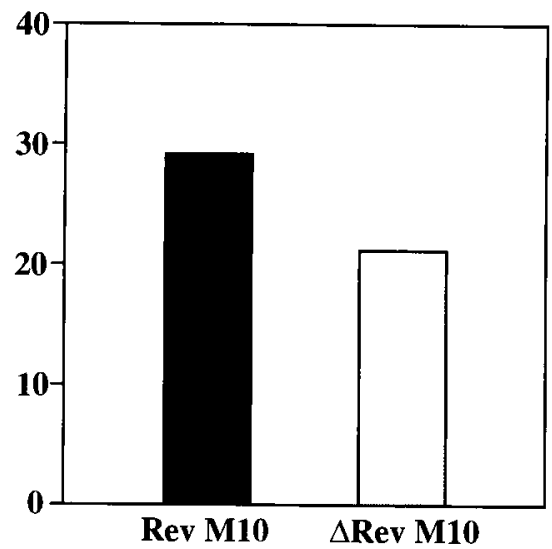

FIG. 2. Cytokine production of Rev M10 or $\Delta$ Rev M10 transduced PBL following stimulation with anti-CD3 antibody. Cells were transduced with linearized RSV/TAR Rev M10 or RSV/TAR $\Delta$ Rev M10 plasmids by particle-mediated gene transfer (A) or by retroviral infection with the Rev M10 or $\Delta$ Rev M10 retroviral vectors (B). After selection in G418 for 12 days, IL-4 and GM-CSF cytokine levels in PBL culture supernatants were determined in the presence or absence of immobilized OKT-3 antibody by ELISA. Fold stimulation in cytokine levels induced by treatment with OKT-3 for 24 hr are shown.

in SCID mice. These experiments examined animals that received infusions of $2 \times 10^{7}-3 \times 10^{8}$ transduced or control nontransduced PBL. No acute toxicity was observed in any animal following adoptive transfer of Rev M10 PBL. Similarly, we failed to detect evidence of toxicity, malignant transformation, or major cytopathology associated with the infusion or abnormal cytokine secretion patterns in Rev M10 PBL up to 21 weeks. These data suggest that using retroviral or particle-mediated gene transfer, the rev M10 gene can be expressed in PBL and safely administered in humans.

\section{ACKNOWLEDGMENTS}

We thank Dr. Richard Jove for helpful discussions and for kindly providing the pZAS 4 plasmid, Donna Gschwend for secretarial assistance, and Karen Carter for computer graphics. This work was supported by a grant from the National Institutes of Health (G.J.N., AI36207; B.A.F., AI33355).

\section{REFERENCES}

CHAUDHARY, V.K., MIZUKAMI, T., FUERST, T.R., FITZGERALD, D.J., MOSS, B., PASTAN, I., and BERGER, E.A. (1988). Selective killing of HIV-infected cells by recombinant human CD4Pseudomonas exotoxin hybrid protein. Nature 335, 369-372.

CULLEN, B.R. (1991). Regulation of HIV-1 gene expression. FASEB J. 5, 2361-2368.

DÜEWEKE, T.J., POPPE, S.M., ROMERO, D.L., SWANEY, S.M., SO, A.G., DOWNEY, K.M., ALTHAUS, I.W., REUSSER, F., BUSSO, M., and RESNICK, L. (1993). U-90152, a potent inhibitor 
of human immunodeficiency virus type 1 replication. Antimicrob. Agents Chemother. 37, 1127-1131.

GREENE, W.C. (1991). Regulation of HIV-1 gene expression. Annu. Rev. Immunol. 8, 453-475.

GROB, P.M., WU, J.C., COHEN, K.A., INGRAHAM, R.H., SHIH, C.K., HARGRAVE, K.D., MCTAGUE, T.L., and MERLUZZI, V.J. (1992). Nonnucleoside inhibitors of HIV-1 reverse transcriptase: Nevirapine as a prototype drug. AIDS Res. Hum. Retroviruses 8, 145-152.

MALIM, M.H., and CULLEN, B.R. (1991). HIV-1 structural gene expression requires the binding of multiple Rev monomers to the viral RRE: implications for HIV-1 latency. Cell 65, 241-248.

MALIM, M.H., FREIMUTH, W.W., LIU, J., BOYLE, T.J., LYLERLY, H.K., CULLEN, B.R., and NABEL, G.J. (1992). Stable expression of transdominant rev protein in human $T$ cells inhibits human immunodeficiency virus replication. J. Exp. Med. 176, 1197-1201.

MOSIER, D.E., GULIZIA, R.J., BAIR D, S.M., WILSON, D.B., SPECTOR, D.H., and SPECTOR, S.A. (1991). Human immunodeficiency virus infection of human-PBL-SCD mice. Science 251, 791-794.

RICHMAN, D., SHIH, C.K., LOWY, I., ROSE, J., PRODANOVICH, P., GOFF, S., and GRIFFIN, J. (1991). Human immunodeficiency virus type 1 mutants resistant to nonnucleoside inhibitors of reverse transcriptase arise in tissue culture. Proc. Natl. Acad. Sci. USA 88, 11241-11245.

SKOOG, M.T., HARGRAVE, K.D., MIGLILETTA, J.J., KOPP, E.B., and MERLUZZI, V.J. (1992). Inhibition of HIV-1 reverse tran- scriptase and virus replication by a non-nucleoside dipyridodiazepinone BI-RG-587 (Nevirapine). Med. Res. Rev. 12, 27-40.

VASUDEVACHARI, M.B., BATTISTA, C., LANE, H.C., PSALLIDOPOULOS, M.C., ZHAO, B., COOK, J., PALMER, J.R., ROMERO, D.L., TARPLEY, W.G., and SALZMAN, N.P. (1992). Prevention of the spread of HIV-1 infection with non-nucleoside reverse transcriptase inhibitors. Virology 190, 269-277.

WOFFENDIN, C., YANG, Z., UDAYKUMAR, XU, L., YANG, N., SHEEHY, M.J., and NABEL, G.J. (1994). Non-viral and viral delivery of a human immunodeficiency virus protective gene into primary human T cells. Proc. Natl. Acad. Sci. USA 91, 11581-11585. ZAGURY, D., BERNARD, J., LEONARD, R., CHEYNIER, R., FLEDMAN, M., SARIN, P.S., and GALLO, R.C. (1986). Long-term cultures of HTLV-III-infected T cells: A model of cytopathology of T-cell depletion in AIDS. Science 231, 850-853.

Address reprint requests to: Dr. Gary Nabel Howard Hughes Medical Institute University of Michigan Medical Center 1150 West Medical Center Drive Ann Arbor, MI 48109-0650

Received for publication November 15, 1994; accepted after revision April 13, 1995. 


\section{This article has been cited by:}

1. Richard A. Morgan, Robert Walker, Charles S. Carter, Ven Natarajan, Jorge A. Tavel, Chris Bechtel, Betsy Herpin, Linda Muul, Zhili Zheng, Shyla Jagannatha, Bruce A. Bunnell, Vicki Fellowes, Julia A. Metcalf, Randy Stevens, Michael Baseler, Susan F. Leitman, Elizabeth J. Read, R. Michael Blaese, H. Clifford Lane. 2005. Preferential Survival of CD4+ T Lymphocytes Engineered with Anti-Human Immunodeficiency Virus (HIV) Genes in HIV-Infected Individuals. Human Gene Therapy, ahead of print050810083459001. [CrossRef]

2. Richard A. Morgan, Robert Walker, Charles S. Carter, Ven Natarajan, Dr. Jorge A. Tavel, Chris Bechtel , Betsy Herpin, Linda Muul, Zhili Zheng, Shyla Jagannatha, Bruce A. Bunnell, Vicki Fellowes , Julia A. Metcalf, Randy Stevens, Michael Baseler, Susan F. Leitman, Elizabeth J. Read, R. Michael Blaese , H. Clifford Lane . 2005. Preferential Survival of CD4+ T Lymphocytes Engineered with Anti-Human Immunodeficiency Virus (HIV) Genes in HIV-Infected IndividualsPreferential Survival of CD4+ T Lymphocytes Engineered with Anti-Human Immunodeficiency Virus (HIV) Genes in HIV-Infected Individuals. Human Gene Therapy 16:9, 1065-1074. [Abstract] [PDF] [PDF Plus]

3. Ananthalakshmi Poluri, Marc van Maanen, Richard E Sutton. 2003. Genetic therapy for HIV/AIDS. Expert Opinion on Biological Therapy 3:6, 951-963. [CrossRef]

4. Claudia Muratori , Ilaria Schiavoni, Gianna Melucci-Vigo , Eleonora Olivetta, Anna Claudia Santarcangelo , Katherina Pugliese, Paola Verani , Maurizio Federico . 2002. Inducible Expression of the $\Delta \mathrm{NGFr} / \mathrm{F} 12 \mathrm{Nef}$ Fusion Protein as a New Tool for Anti-Human Immunodeficiency Virus Type 1 Gene TherapyInducible Expression of the $\triangle \mathrm{NGFr} / \mathrm{F} 12 \mathrm{Nef}$ Fusion Protein as a New Tool for Anti-Human Immunodeficiency Virus Type 1 Gene Therapy. Human Gene Therapy 13:14, 1751-1766. [Abstract] [PDF] [PDF Plus]

5. Franck Morel, Suzan Salimi , Judit Markovits , Timothy W. Austin , Ivan Plavec . 1999. Hematologic Recovery in Mice Transplanted with Bone Marrow Stem Cells Expressing Anti-Human Immunodeficiency Virus GenesHematologic Recovery in Mice Transplanted with Bone Marrow Stem Cells Expressing Anti-Human Immunodeficiency Virus Genes. Human Gene Therapy 10:17, 2779-2787. [Abstract] [PDF] [PDF Plus]

6. Zi-Qing Ye, Ping Qiu, Joseph K. Burkholder, Joel Turner, Jerilyn Culp, Tim Roberts, Nasrollah T. Shahidi, Ning-Sun Yang. 1998. Cytokine Transgene Expression and Promoter Usage in Primary CD34+ Cells Using Particle-Mediated Gene DeliveryCytokine Transgene Expression and Promoter Usage in Primary CD34+ Cells Using Particle-Mediated Gene Delivery. Human Gene Therapy 9:15, 2197-2205. [Abstract] [PDF] [PDF Plus]

7. Javier Chinen, Estuardo Aguilar-Cordova, Derek Ng-Tang, Dorothy E. Lewis, John W. Belmont. 1997. Protection of Primary Human T Cells from HIV Infection by Trev: A Transdominant Fusion GeneProtection of Primary Human T Cells from HIV Infection by Trev: A Transdominant Fusion Gene. Human Gene Therapy 8:7, 861-868. [Abstract] [PDF] [PDF Plus]

8. Karen Kearns, Ingrid Bahner, Gerhard Bauer, Sui-Fang Wei, Penelope Valdez, Sarah Wheeler, Lin Woods, Robert Miller, Dennis Casciato, Jeffrey Galpin, Joseph Church, Donald B. Kohn. 1997. Suitability of Bone Marrow from HIV-1-Infected Donors for Retrovirus-Mediated Gene TransferSuitability of Bone Marrow from HIV-1-Infected Donors for Retrovirus-Mediated Gene Transfer. Human Gene Therapy 8:3, 301-311. [Abstract] [PDF] [PDF Plus] 